\title{
Peran Retrun On Assets (ROA) Sebagai Variabel Mediasi Pada Pengaruh Non Performing Loan (NPL) Dan BI Rate Terhadap Harga Saham Bank BUMN Periode $2011-2020$
}

\author{
Yayan Nasikin ${ }^{1}$, Indah Yuliana ${ }^{2 *}$ \\ Magister Ekonomi Syariah UIN Maulana Malik Ibrahim Malang ${ }^{1,2}$ \\ yayannasikin@gmail.com, indahoty@manajemen.uin-malang.ac.id.
}

$\begin{array}{ll}\text { *Corresponding } & \text { Author } \\ \text { Diajukan } & : \text { 27 Desember } 2021 \\ \text { Disetujui } & : \text { 30 Desember 2021 } \\ \text { Dipublikasi } & : \text { 1 Januari } 2022\end{array}$

\section{ABSTRACT}

The purpose of this study is to provide empirical evidence regarding the direct effect of Non Performing Leon (NPL) and BI Rate on Return On Assets (ROA) and stock prices, indirect effect of Non Performing Leon (NPL) and BI Rate on stock prices through Return On Assets (ROA) as a mediating variable in state-owned banks for the period 2011 -2020. This type of research is quantitative research. The data analysis technique used is multiple linear regression and mediation test using Eviews 12 program and Sobel Test Online. The results of this study show that simultaneously Non Performing Loans (NPL), BI Rate and Return On Assets (ROA) have a significant effect on stock prices. Partially 1). Non-performing loans (NPL) have a negative and significant impact on Return On Assets (ROA). 2) BI Rate has a positive but not significant impact on Return On Assets (ROA). 3). NPL (Non Performing Loan) has a negative and significant impact on stock prices. 4). BI Rate has a negatif and significant impact on stock prices. 5) Return on Assets (ROA) has a positive and significant impact on stock prices. Return on Assets (ROA) as a mediating variable is able to mediate the effect of non-performing loans (NPL) on stock prices, however, Return On Assets (ROA) does not mediate the effect of the BI Rate on stock prices.

Keywords: Non Performing Loan (NPL); BI Rate; Retrun On Assets (ROA); Stock Prices

\section{PENDAHULUAN}

Salah satu bentuk pasar keuangan yang digunakan perusahaan untuk menjual sahamnya adalah Pasar modal, dimana pelaku pasar yaitu individu atau badan usaha yang memiliki kelebihan dana (surplus fund) melakukan investasi pada surat berharga yang ditawarkan oleh emiten atau perusahaan (Undang-Undang No. 8 Tahun 1995 Tentang Pasar Modal., n.d.). Melalui pasar modal perusahaan mampu meningkatkan kinerja, melakukan inovasi bisnis dan melakukan ekspansi pasar. Hal ini disebabkan perusahaan mendapatkan sumber pendanaan yang diperoleh melalui penjualan saham. Selain itu, melalui pasar modal perusahaan juga dapat meningkatkan citranya dimasyarakat (Haq et al., 2020). Untuk itu kinerja bank merupakan hal yang penting karena mencerminkan bank dalam mengelola aspek permodalan dan asetnya dalam mendapatkan laba (Devi, 2016).

Dalam penelitian (Nurhayati \& Nur Bhakti Pertiwi, 2021) dijelaskan bahwa harga saham suatu perusahaan mencerminkan kinerja dan nilai perusahaan. Artinya apabila harga saham naik maka mengindikasikan kinerja perusahaan baik dan akan memperbesar nilai perusahaan dimata investor, dan Sebaliknya perusahaan yang mengalami kerugian dan tidak mampu bertahan dalam persaingan akan menyebabkan investasinya menurun, hal tersebut ditandai dengan penurunan harga saham dan jumlah lembar saham yang beredar (Nurhayati \& Nur Bhakti Pertiwi, 2021). Bank Umum Badan Usaha Milik Negara (BUMN) merupakan bank yang mayoritas 
kepemilikannya, dimiliki oleh Negara. Harga saham bank BUMN dalam perkembangannya juga mengalami fluktuasi dipasar modal.

Gambar 1. Harga saham Bank BUMN

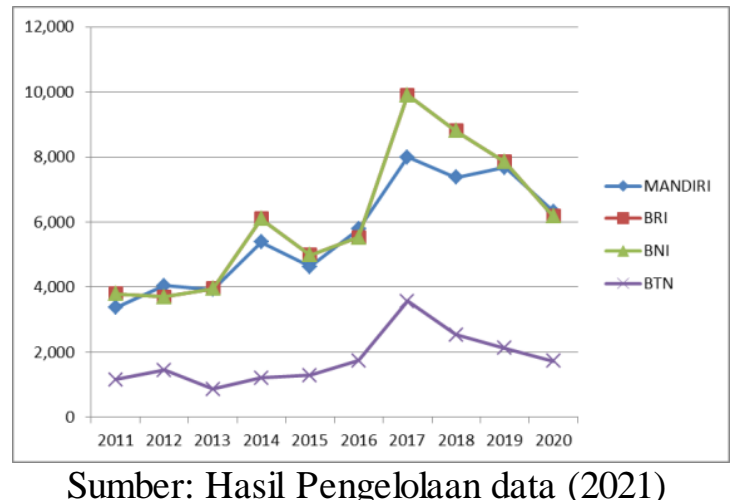

Grafik diatas menunjukan harga saham masing - masing Bank BUMN mengalami fluktuasi yang cenderung sama pada level harga yang berbeda. Dapat terlihat bahwa, harga saham PT. Bank Rakyat Indonesia, Tbk. dan PT. Bank Negara Indonesia, Tbk mengalami kenaikan harga tertinggi pada tahun 2017 pada harga Rp.10.000 per lembar saham. Menurut (Devi, 2016) Investor dalam mengambil keputusan investasinya pada pasar modal mempertimbangkan faktor fundamental. Informasi yang bersifat fundamental diperoleh dari kondisi intern perusahaan. Non Performing Loan (NPL) dan Retrun On Assets (ROA) merupakan salah satu rasio fundamental yang menjadi acuan investor sebelum melakukan pembelian saham pada sektor perbankan (Alaagam, 2019).

Non Performing Leon (NPL) dan Retrun On Assets (ROA) penting untuk dianalisis karena kegiatan bisnis utama perbankan adalah menghimpun dana dan menyalurkannya dalam bentuk pinjaman. Dengan mengetahui Retrun On Assets (ROA), investor dapat mengetahui kinerja manajemen bank dalam memperoleh laba atau keuntungan (profitabilitas) dalam periode tertentu, sedangkan dengan mengetahui Non Performing Leon (NPL), investor dapat mengukur tingkat kredit bermaslah pada bank dalam periode waktu tertentu (Amos John, 2018).

Pendapat diatas mengantarkan pada kesimpulan bahwa Non Performing Loan (NPL) akan memiliki dampak langsung pada Retrun On Assets (ROA) dan juga akan memiliki dampak tidak langsung pada harga saham perbankan. Berdasarkan studi yang dilakukan (Uthami Putri Warsa \& Mustanda, 2016) menjelaskan bahwa Non Performing Loan (NPL) berpengaruh negatif dan signifikan terhadap Retrun On Assets (ROA) dan Retrun On Assets (ROA) berpengaruh positif dan signifikan terhadap harga saham (Wahyuni Latif et al., 2021). Hasil yang berbeda ditunjukan pada penelitian yang dilakukan oleh (Rohimah, 2021) bahwa Non Performing Loan (NPL) tidak berpengaruh terhadap Retrun On Assets (ROA), sedangkan Retrun On Assets (ROA) menurut (Devi, 2016) berpengaruh negatif terhadap harga saham.

Berdasarkan studi yang dilakukan oleh (Kusumaningrum \& Iramani, 2020) menjelaskan Non Performing Leon (NPL) memiliki pengaruh negatif dan signifikan terhadap harga saham melalui Retrun On Assets (ROA) sebagai variabel mediasi. Akan tetapi, meninjau penelitian yang dilakukan oleh (Munawar \& Maulana, 2019) menunjukan tidak terdapat pengaruh signifikan Non Performing Loan (NPL) terhadap harga saham dengan Return On Assets (ROA) sebagai variabel intervening. Penelitian lain yang dilakukan (Brastama \& Yadnya, 2020) variabel Non Performing Loan (NPL) berpengaruh terhadap harga saham melalui Retrun On Assets (ROA).

Selain faktor fundamental, faktor teknikal juga merupakan faktor penting yang mempengaruhi keputusan investor sebelum membeli saham pada sektor perbankan. Informasi teknikal diperoleh dari luar perusahaan, seperti kebijakan ekonomi, politik, financial dan faktor lainnya (Devi, 2016). BI rate adalah salah satu faktor teknikal yang berpengaruh langsung pada sektor perbankan. BI rate merupakan kebijakan Bank Indonesia yang merepresentasi perubahan perilaku ekonomi pada sektor rill (Bank Indonesia, 2020). 
Gambar 2. BI Rate

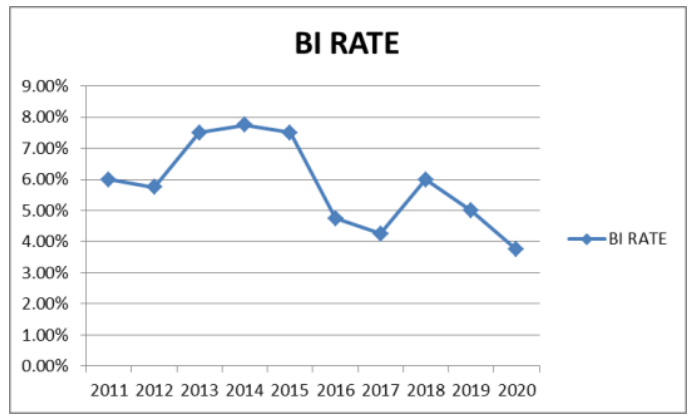

Sumber: Hasil Pengelolaan data (2021)

BI Rate dalam kurun waktu 10 tahun terakhir mengalami fluktuatif dan cenderung menurun terlebih pada tahun 2018 sampai 2020. Bank Indonesia pada umumnya akan menaikkan BI Rate apabila inflasi ke depan diperkirakan melampaui sasaran yang telah ditetapkan. Sebaliknya Bank Indonesia akan menurunkan BI Rate apabila inflasi ke depan diperkirakan berada di bawah sasaran yang telah ditetapkan/anchoring inflation expectations (Bank Indonesia, 2020). BI rate yang mengalami fluktuasi akan berdampak pada perilaku masyarakat dalam menggunakan produk perbankan dan juga berdampak pada kinerja keuangan bank dan harga saham.

Berdasarkan kajian yang dilakukan (Kurniawati et al., 2018), (Darmawan et al., 2020) BI Rate berpengaruh negatif dan signifikan terhadap Retrun On Assets (ROA) dan Retrun On Assets (ROA) menurut (Devi, 2016) berpengaruh negatif terhadap harga saham. Hasil berbeda ditunjukan oleh kajian yang dilakukan (Rachmawati \& Marwansyah, 2019), hasil kajian ini menunjukan bahwa BI Rate memiliki pengaruh positif dan signifikan terhadap Retrun On Assets (ROA) dan Retrun On Assets (ROA) berpengaruh positif dan signifikan terhadap harga saham (Wahyuni Latif et al., 2021). Sedangkan menurut (Kusumaningrum \& Iramani, 2020), Retrun On Assets (ROA) mampu memediasi pengaruh antara suku bunga terhadap harga saham. Namun Studi yang dilakukan (Wiratno et al., 2018) Retrun On Assets (ROA) tidak memediasi hubungan antara suku bunga dengan return saham.

Berdasarkan latar belakang yang telah dijelaskan diatas, penelitian ini bertujuan untuk menganalisis dampak langsung maupun tidak langsung, pengaruh Non Performing Loan (NPL) dan BI Rate terhadap harga saham melalui Retrun On Assets (ROA) sebagai variabel mediasi pada Bank BUMN Periode 2011 - 2020. Berdasar tujuan penelitian tersebut maka dapat digambarkan kerangka pemikiran sebagai berikut :

Gambar 3. Kerangka Berfikir

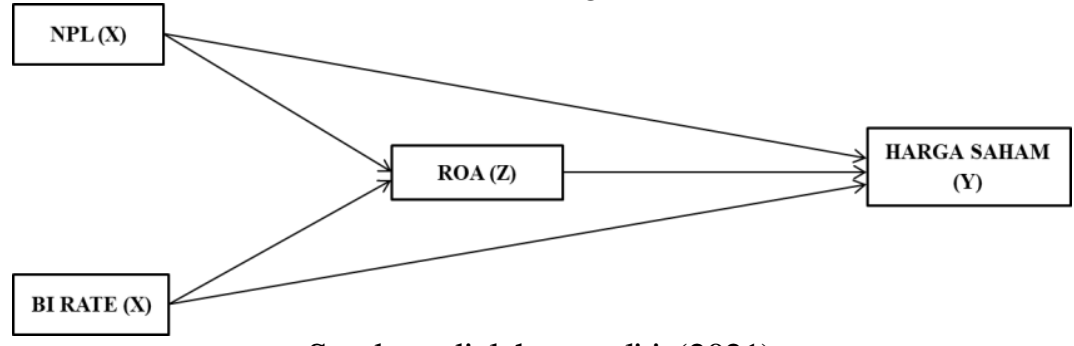

Sumber: diolah peneliti (2021)

\section{STUDI LITERATUR}

\section{Pengaruh Non Performing Loan (NPL) dan Retrun On Assets (ROA)}

Rasio Non Performing Loan (NPL) merupakan indikator keuangan yang penting bagi investor yang ingin menilai tingkat kesehatan bank. Kredit bermasalah (NPL) adalah kredit yang berkualitas buruk, mencurigakan, atau bermasalah. Non Performing Loan (NPL) juga mengacu pada situasi di mana debitur tidak dapat memenuhi kewajibannya kepada bank, terutama kebutuhan untuk membayar pembayaran yang dijanjikan (Rumah.com, 2021). Temuan (Osuagwu, 2014) menunjukan bahwa profitabilitas bank sangat ditentukan oleh risiko kredit. 
Artinya Non Performing Loan (NPL) yang tinggi akan berdampak pada laba yang menurun, begitu pun sebaliknya. Berdasarkan studi yang dilakukan oleh (Martiningtiyas \& Nitinegeri, 2020) bahwa Non Performing Loan (NPL) berpengaruh negatif dan signifikan terhadap Retrun On Assets (ROA). Hal ini juga sejalan dengan penelitian yang dilakukan oleh (Uthami Putri Warsa \& Mustanda, 2016), (Rachmawati \& Marwansyah, 2019), (Darmawan et al., 2020) bahwa rasio kredit bermasalah yang tinggi memiliki pngaruh yang nyata terhadap rasio keutnungan.

Berdasarkan uraian ringkas teori dan hasil penelitian terdahulu, sehingga hipotesis yang dibangun dalam penelitian ini adalah:

$\mathrm{H}_{1} \quad$ : Non Performing Loan (NPL) negatif berpengaruh terhadap Retrun On Assets (ROA).

\section{Pengaruh BI Rate dan Retrun On Assets (ROA)}

BI Rate adalah kebijakan yang ditetapkan Bank Indonesia setiap bulan setelah rapat dewan gubernur untuk mengatur keuangan dengan memperhatikan kondisi perekonomian suatu negara. Kebijakan ini menjadi pedoman bagi lembaga keuangan dan masyarakat umum dalam melakukan transaksi moneter dan keuangan (OCBC NISP, 2021). Semakin tinggi BI rate, semakin tinggi pula suku bunga pinjaman bank. Hal ini akan mengubah sikap masyarakat terhadap penggunaan produk perbankan dalam bentuk kredit, yang mengakibatkan penurunan penyaluran kredit dan penurunan pendapatan perbankan. Berdasarkan kajian yang dilakukan oleh (Sawitri, 2018) BI Rate berpengaruh negatif dan signifikan terhadap Retrun On Assets (ROA). Kajian lain yang mendukung penelitian tersebut antara lain (Dayu, 2015), (Kurniawati et al, 2018), (Rachmawati \& Marwansyah, 2019), (Darmawan et al., 2020) bahwa suku bunga yang tinggi akan menurun rasio profitabilitas secara nyata pada bank.

Berdasarkan uraian ringkas teori dan hasil penelitian terdahulu, sehingga hipotesis yang dibangun dalam penelitian ini adalah :

$\mathrm{H}_{1} \quad$ : BI Rate berpengaruh negatif terhadap Retrun On Assets (ROA).

\section{Pengaruh Retrun On Assets (ROA) dan Harga Saham}

Rasio Return on Assets (ROA) adalah salah satu statistik keuangan yang paling penting, terutama bagi investor yang ingin menilai kesehatan bank sebelum membeli saham. Kemampuan manajemen bank untuk menghasilkan keuntungan selama periode waktu tertentu disebut sebagai return on assets (ROA) (Amos John, 2018). Rasio Retrun On Assets (ROA) dihitung dengan membandingkan total asset terhadap laba bank. Return On Assets (ROA) memberikan kontribusi unik terhadap prediktor harga saham yang signifikan secara statistik, artinya jika Return On Assets (ROA) tinggi dan stabil dalam waktu lama, harga saham akan naik (Milosevic-Avdalovic \& Milenkovic, 2017). Berdasarkan penelitian yang dilakukan oleh (Wahyuni Latif et al., 2021), Retrun On Assets (ROA) berpengaruh positif dan signifikan terhadap harga saham. Studi lain yang dilakukan oleh (Purnamasari, 2015), (Bustani, 2020), (Nurhayati \& Nur Bhakti Pertiwi, 2021), (Herawati \& Putra, 2018), bahwa apabila rasio Retrun On Assets (ROA) pada laporan keuangan bank meningkat, akan berdampak pada naiknya harga saham secara signifikan.

Berdasarkan uraian ringkas teori dan hasil penelitian terdahulu, sehingga hipotesis yang dibangun dalam penelitian ini adalah :

$\mathrm{H}_{1} \quad$ : Retrun On Assets (ROA) positif berpengaruh terhadap harga saham.

\section{Pengaruh Non Performing Loan (NPL) dan Harga Saham}

Salah satu rasio fundamental perbankan adalah rasio Non Performing Loan (NPL). Hal ini karena kegiatan utama perbankan adalah menghimpun dana dari masyarakat dan menyalurkannya kembali dalam bentuk pinjaman atau kredit, rasio ini penting untuk dipahami investor. Angka ini dihitung dengan membagi total pinjaman dengan kredit bermasalah (El - Heze, 2021). Semakin tinggi Non Performing Loan (NPL), maka semakin banyak pula kredit bermasalah yang dimiliki bank. Meningkatnya jumlah kredit bermasalah (NPL) mengindikasikan manajemen perbankan kesulitan mencari debitur yang berkualitas. Semakin baiknya rasio Non Performing Loan (NPL) 
pada bank, maka bank akan memiliki kemampuan dalam menghasilkan laba yang akan berdampak pada harga saham bank tersebut. Peningkatan harga saham merupakan hal yang diinginkan para investor karena akan meningkatkan return sahamnya. Menurut (Nurhayati \& Nur Bhakti Pertiwi, 2021) Non Performing Loan (NPL) memiliki pengaruh negatif tetapi tidak signiffikan terhadap harga saham. (Haq et al., 2020), (Devi, 2016), (Munawar \& Maulana, 2019), (Brastama \& Yadnya, 2020) juga menjelaskan bahwa Non Performing Loan (NPL) memiliki dampak negatif tetapi tidak berarti terhadap harga saham.

Berdasarkan uraian ringkas teori dan hasil penelitian terdahulu, sehingga hipotesis yang dibangun dalam penelitian ini adalah :

$\mathrm{H}_{1} \quad$ : Non Performing Loan (NPL) negatif berpengaruh terhadap harga saham.

\section{Pengaruh BI Rate dan Harga Saham}

Salah satu kebijakan moneter yang digunakan untuk mengendalikan jumlah uang beredar dimasyarakat adalah BI Rate. Kebijakan ini menggunakan saluran perbankan dalam penerapannya (Zulkhibri, 2018). Apabila BI rate naik maka suku bunga pada industri perbankan juga akan melakukan penyesuaian mengikuti tren kenaikan BI rate. Hal ini akan mempengaruhi perilaku masyarakat dalam meminjam di perbanakan. Secara langsung BI Rate akan mempengaruhi kinerja keuangan bank dan akan berdampak pada harga saham. Berdasarkan hasil kajian yang dilakukan oleh (Türsoy, 2017) bahwa Suku bunga memiliki pengaruh negatif terhadap harga saham. Penelitian tersebut juga sejalan dengan kajian yang dilakukan oleh (Arhenful et al., 2021) dan (Narayan et al., 2014) bahwa suku bunga berpengaruh negatif dan signifikan terhadap harga saham.

Berdasarkan uraian ringkas teori dan hasil penelitian terdahulu, sehingga hipotesis yang dibangun dalam penelitian ini adalah :

$\mathrm{H}_{1} \quad$ : BI Rate berpengaruh negatif terhadap harga saham.

\section{Peran Retrun On Assets (ROA) Sebagai Variabel Mediasi Pada Pengaruh Non Performing Loan (NPL) Terhadap Harga Saham.}

Harga saham diartikan sebagai harga yang tercipta di pasar bursa pada saat tertentu dan harga saham tersebut ditentukan oleh permintaan dan penawaran oleh pelaku pasar (Nurhayati \& Nur Bhakti Pertiwi, 2021). Harga saham mencerminkan nilai perusahaan yang tergambar melalui kinerja keuangan bank (Indriani \& Dewi, 2016). Retrun On Assets (ROA) sebagai rasio yang digunakan unuk mengukur kinerja bank, akan sangat dipengaruh oleh aktifitas bisnis bank sehingga akan mempengaruhi harga saham. (Kusumaningrum \& Iramani, 2020) menjelaskan bahwa Non Performing Leon (NPL) memiliki pengaruh negatif dan signifikan terhadap harga saham melalui Retrun On Assets (ROA) sebagai variabel mediasi. Sejalan dengan hasil studi yang dilakukan (Munawar \& Maulana, 2019), (Brastama \& Yadnya, 2020) bahwa Retrun On Assets (ROA) mampu memediasi pengaruh Non Performing Leon (NPL) terhadap harga saham.

Berdasarkan uraian ringkas teori dan hasil penelitian terdahulu, sehingga hipotesis yang dibangun dalam penelitian ini adalah :

$\mathrm{H}_{1} \quad$ : Retrun On Assets (ROA) mampu memediasi pengaruh Non Performing Leon (NPL) terhadap harga saham.

\section{Peran Retrun On Assets (ROA) Sebagai Variabel Mediasi Pada Pengaruh BI Rate Terhadap Harga Saham}

BI rate merupakan kebijakan Bank Indonesia untuk mempengaruhi jumlah uang yang beredar dimasyarakat (Bank Indonesia, 2020). Semakin tinggi BI rate akan berpengaruh pada suku bunga pinjaman pada perbanakan. Hal terebut akan merubah perilaku masyarakat dalam menggunakan produk perbankan berupa kredit. Dijelaskan oleh (Darmawan et al., 2020) suku bunga memiliki pengaruh terhadap kinerja keunagan yaitu Retrun On Assets (ROA) Berdasarkan kajian yang dilakukan oleh (Kurniawati et al., 2018), BI Rate berpengaruh negatif dan signifikan terhadap 
Retrun On Assets (ROA). Berdasarkan penelitian yang dilakukan (Kusumaningrum \& Iramani, 2020), Retrun On Assets (ROA) mampu memediasi pengaruh antara suku bunga terhadap harga saham.

Berdasarkan uraian ringkas teori dan hasil penelitian terdahulu, sehingga hipotesis yang dibangun dalam penelitian ini adalah:

$\mathrm{H}_{1} \quad$ : Retrun On Assets (ROA) mampu memediasi pengaruh BI Rate terhadap harga saham.

\section{METODE}

Penelitian ini merupakan jenis penelitian kuantitatif, penelitian kuantitatif digunakan untuk mengetahui dampak atau keterkaitan antara dua variabel atau lebih (Sugiyono, 2017). Penelitian ini dilakukan pada 4 bank Badan Usaha Milik Negara (BUMN) yang telah melantai di bursa saham dan terdaftar di Otoritas Jasa Keuangan (OJK) pada periode 2011 - 2020. Bank - bank tersebut antara lain PT. Bank Rakyat Indonesia, Tbk, PT. Bank Negara Indonesia, Tbk, PT. Bank Tabungan Negara, Tbk, dan PT. Mandiri, Tbk.

Populasi dalam penelitian ini adalah harga saham 4 bank Badan Usaha Milik Negara (BUMN) yang terdaftar di Bursa Efek Indonesia (BEI) sebanyak 40 data selama 10 tahun terakhir yaitu dari periode tahun 2011 sampai dengan 2020. Pengambilan sampel dilakukan dengan purposive sampling. Sampel yang digunakan dalam penelitian ini adalah harga saham 4 bank Badan Usaha Milik Negara (BUMN) yang terdaftar di Bursa Efek Indonesia (BEI) sebanyak 40 data selama 10 tahun. Sumber data penelitian ini untuk harga saham diperoleh dari https://www.idx.co.id, sedangkan untuk data BI Rate diperoleh dari laman resmi Bank Indonesia (BI) yatu https://www.bi.go.id, kemudian untuk rasio keuangan bank diperoleh dari website bank masing - masing yaitu, https://bri.co.id, https $/ /$ bni.co.id, https://btn.co.id, https://bankmandiri.co.id.

Untuk metode analisis dalam penelitian ini, peneliti menggunakan analisis regresi linier berganda dengan mengggunakan software Eviews. Analisis regresi linier berganda dilakukan untuk melihat apakah variabel independen $(\mathrm{X})$ berpengaruh terhadap variabel dependen $(\mathrm{Y})$. Analisis regresi linier berganda dalam penelitian ini, dilakukan pada pengaruh variabel independen yaitu, NPL (X1) dan BI Rate (X2) terhadap variabel dependen (Y) yaitu, ROA (Y) dan juga dilakukan pada variabel independen yaitu, NPL (X1), BI Rate (X2) dan ROA (X3) terhadap variabel dependen (Y) yaitu, harga saham (Y). Kemudian peneliti juga menggunakan software Sobel Test Online untuk melihat peran variabel mediasi (Z) yaitu ROA (Z) pada hubungan antara variabel independen (X) yaitu NPL (X1), BI Rate (X2) dan variabel dependen (Y) yaitu harga saham (Y).

Sebelum dilakukan analisis data, karena data yang digunakan dalam penelitian ini adalah data panel, perlu dilakukan pemilihan model yang tepat dengan melakukan uji chow, hausman, dan lagrange. Setelah menemukan model yang tepat, dilakukan uji asumsi klasik antara lain, uji normalitas data, uji multikolonieritas, uji heteroskedastisitas dan uji autokorelasi. Kemudian setelah masing - masing tahapan terpenuhi maka dilakukan analisis regresi linier berganda dengan persamaan sebagai berikut :

Keterangan :

$$
Y=a+\beta 1 \mathrm{X} 1+\beta 2 \mathrm{X} 2+\beta 3 \mathrm{X} 3+\mathrm{e}
$$

$\begin{array}{lll}\mathrm{Y} & =\text { Harga Saham } \\ a & & =\text { Konstata } \\ \beta 1, \beta 2, \beta 3 & & =\text { Koefisien Regresi } \\ \mathrm{X} 1 & & =\text { Non Performing Loan (NPL) } \\ \mathrm{X} 2 & & =\text { BI Rate } \\ \mathrm{X} 3 & & \text { Retrun On Assets (ROA) } \\ \mathrm{e} & & =\text { Error }\end{array}$




\section{Pemilihan Model Regresi}

\section{HASIL}

Common Effect Model (model efek umum), Fixed Effect Models (model efek tetap), dan Model Efek Acak (model efek acak) adalah tiga strategi yang bisa digunakan untuk memperkirakan parameter model apabila memakai data panel (Gujarati, 2015). Uji Chow, Hausman, dan Lagrange kemudian akan digunakan untuk menentukan teknik estimasi data panel mana yang akan digunakan. Digunakan Uji Chow untuk menentukan model estimasi dalam membuat regresi antara Common Effect Model (CEM) dan Fixed Effect Model (FEM), dengan hasil pengujian sebagai berikut:

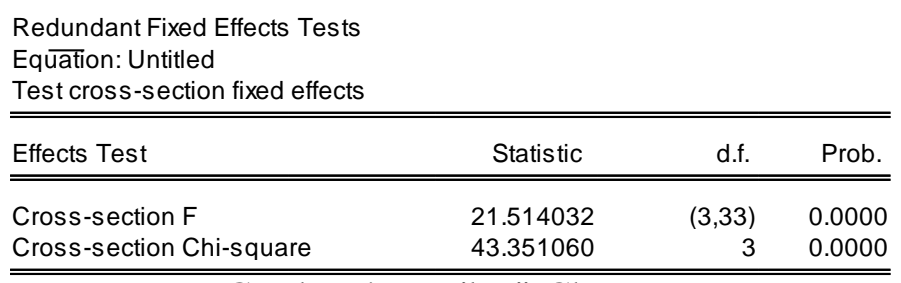

Gambar 4. Hasil Uji Chow

Sumber: Hasil Pengelolaan data (2021)

Berdasarkan hasil pengujian diatas diperoleh nilai probabilitas 0.00 , dimana nilai probabilitas 0.00 lebib kecil dari 0.05, sehingga perkiraan model yang diterapkan adalah Fixed Effect Model (FEM). Selanjutnya Uji Hausman digunakan untuk menentukan model estimasi antara Fixed Effect Model (FEM) dan Random Effect Model (REM) dalam membentuk regresi, dengan hasil pengujian sebagai berikut :

\begin{tabular}{|c|c|c|c|}
\hline Test Summary & Chi-Sq. Statistic & Chi-Sq. d.f. & Prob. \\
\hline Cross-section random & 0.000000 & 3 & 1.0000 \\
\hline
\end{tabular}

Gambar 5. Hasil Uji Hausman

Sumber: Hasil Pengelolaan data (2021)

Berdasarkan hasil dari uji Hausman pada Tabel diatas, diperoleh nilai probabilitas adalah sebesar 1.00. Karena nilai probabilitas 1.00 lebih besar 0,05, maka model estimasi yang digunakan adalah model Random Effect Model (REM).

\section{Uji Asumsi Klasik}

Regresi linier data panel didasarkan pada General Least Square (GLS), maka uji asumsi klasik boleh tidak digunakan jika hasil pengujian model data panel menunjukkan hasil Fixed Effect Model (FEM) atau Random Effect Model (REM). Namun jika hasil pengujian model data panel menunjukkan hasil Common Effect Model (CEM), maka harus memakai uji asumsi klasik karena regresi linier didasarkan pada Ordinary Least Square (OLS) (Gujarati, 2015). Meskipun demikian, uji asumsi sederhana masih digunakan untuk menentukan apakah model yang dibuat sesuai dengan standar BLUE (Best Linear Unbias Estimator).

Uji Normalitas

Uji Jarque-Bera (J-B) digunakan untuk menguji normalitas residual pada studi ini, dengan tingkat signifikansi $\alpha=0,05$. Hasil pengujian digambarkan dalam diagram di bawah ini. 


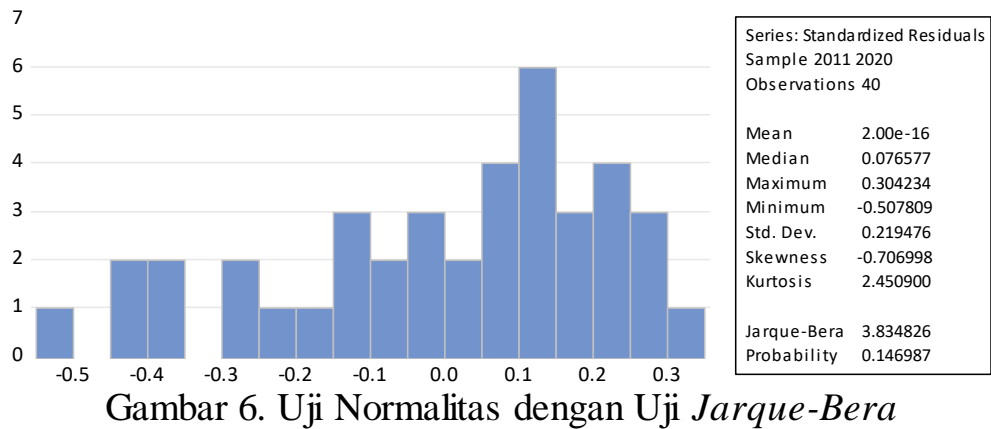

Sumber: Hasil Pengelolaan data (2021)

Nilai probabilitas dari statistik J-B adalah 3,83426, dan nilai probabilitasnya adalah 0,146987, seperti yang terlihat pada grafik di atas. Karena nilai probabilitas 0,067510 melebihi kriteria signifikansi 0,05 . Hal ini dapat ditentukan bahwa data memenuhi asumsi normal.

\section{Uji Multikolinearitas}

Menurut (Ghozali, 2015), multikolinearitas didefinisikan sebagai korelasi yang relatif kuat antara variabel independen, yang lebih besar dari 0,9. Untuk menguji gejala multikolinearitas dapat menggunakan nilai korelasi antar variabel pada matriks. Tabel berikut menunjukkan hasil pengujian multikolinearitas:

\begin{tabular}{|ccccc|}
\hline & $\mathrm{HS}$ & $\mathrm{NPL}$ & $\mathrm{Bl}$ & $\mathrm{ROA}$ \\
$\mathrm{HS}$ & 1.000000 & -0.349146 & -0.279747 & 0.414866 \\
$\mathrm{NPL}$ & -0.349146 & 1.000000 & -0.359794 & -0.543409 \\
$\mathrm{BI}$ & -0.279747 & -0.359794 & 1.000000 & 0.268928 \\
ROA & 0.414866 & -0.543409 & 0.268928 & 1.000000 \\
\hline
\end{tabular}

Gambar 7. Uji Multikolinearitas dan Matriks korelasi

Sumber: Hasil Pengelolaan data (2021)

Berdasarkan tabel di atas, tidak terdapat bukti multikolinearitas antar variabel bebas. Karena variabel bebas memiliki korelasi kurang dari 0,9.

\section{Uji Autokore lasi}

Uji Durbin-Watson dapat digunakan untuk membuat asumsi tentang independensi residual (non-autokorelasi). Uji Durbin-Watson memiliki rentang statistik mulai dari 0 sampai 4. Nilai statistik uji Durbin-Watson yang kurang dari 1 atau lebih besar dari 3 disebut autokorelasi.

\begin{tabular}{lrlr}
\hline \hline R-sqūared & 0.050876 & Mean dependent var & 0.045371 \\
Adjusted R-squared & -0.028218 & S.D. dependent var & 0.053852 \\
S.E. of regression & 0.054606 & Akaike info criterion & -2.882689 \\
Sum squared resid & 0.107347 & Schwarz criterion & -2.713801 \\
Log likelihood & 61.65378 & Hannan-Quinn criter. & -2.821624 \\
F-statistic & 0.643234 & Durbin-Watson stat & 1.718301 \\
Prob(F-statistic) & 0.592259 & & \\
\hline \hline
\end{tabular}

Gambar 8. Uji Autokorelasi Dengan Durbin Watson

Sumber: Hasil Pengelolaan data (2021)

Statistik Durbin-Watson memiliki nilai 1,768006 berdasarkan temuan uji Durbin-Watson yang ditunjukkan di atas. Nilai statistik Durbin-Watson antara 1 dan 3, yaitu 1.768006 dimana lebih besar dari 1 dan kurang dari 3, hal ini menunjukkan bahwa asumsi non-autokorelasi terpenuhi. Dengan kata lain, residu tidak menunjukkan tanda-tanda autokorelasi yang berlebihan.

\section{Uji Hete ros kedastisitas}

Uji Breusch-Pagan digunakan untuk menentukan heteroskedastisitas dalam penelitian ini. Uji Breusch-Pagan ini digunakan untuk mengetahui apakah suatu model memiliki heteroskedastisitas. Pengujian ini dilakukan dengan membandingkan nilai probabilitas Obs*Rsquare dengan tingkat signifikansi (alpha). 
Owner: Riset \& Jurnal Akuntansi

e-ISSN : 2548-9224 | p-ISSN : 2548-7507

Volume 6 Nomor 1, Januari 2022

DOI : https $/ /$ doi.org/10.33395/owner.v6i1.616

\begin{tabular}{|llll|}
\hline \multicolumn{4}{l}{ Heteroskedasticity Test: Breusch-Pagan-Godfrey } \\
Null hypothesis: Homoskedasticity \\
\hline \hline F-statistic & 0.643234 & Prob. F(3,36) & 0.5923 \\
Obs ${ }^{*}$ R-squared & 2.035031 & Prob. Chi-Square(3) & 0.5652 \\
Scaled explained SS & 1.132069 & Prob. Chi-Square(3) & 0.7693 \\
\hline \hline
\end{tabular}

Gambar 9. Uji Heteroskedastisitas Dengan uji Breusch-Pagan

Sumber: Hasil Pengelolaan data (2021)

Setelah dilakukan uji Breusch-Pagan, diperoleh nilai Obs*R-square sebesar 2,035 dimana lebih besar dari nilai signifikansi (alpha) yaitu 0.05. sehingga dapat disimpulkan tidak terjadi heteroskedastisitas.

\section{Uji Hipotesis}

Analisis koefisien, pengujian pengaruh simultan (uji F), uji determinasi dan pengujian pengaruh parsial (uji t) akan digunakan untuk menilai hipotesis. Pengujian tersebut dilakukan pada substruktur I dan substruktur II. Berikut substruktur tersebut :

Gambar 10. substruktur I

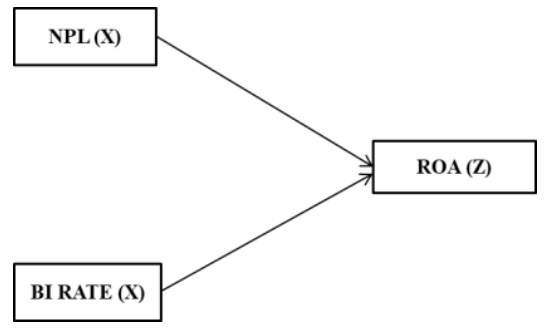

Gambar 11. substruktur II

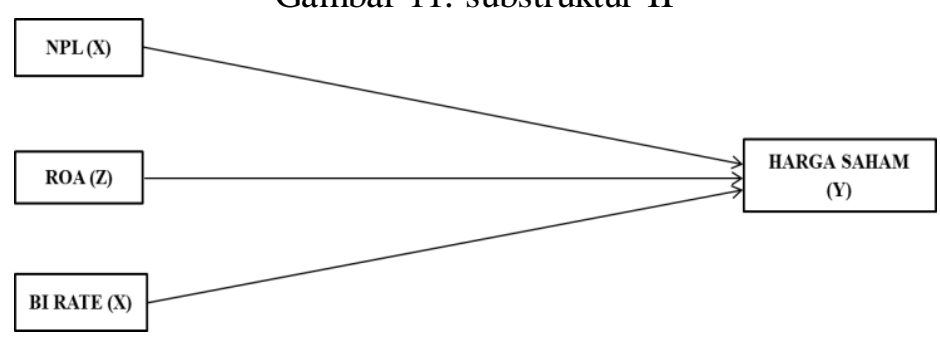

Uji Signifikansi Pengaruh Simultan (Uji F)

Uji Signifikansi Pengaruh Simultan (uji F) substruktur I dan substruktur II bertujuan untuk menguji pengaruh variabel bebas secara bersama-sama atau simultan terhadap variabel terikat. Berikut adalah hasil Uji Signifikansi Pengaruh Simultan (Uji F).

\begin{tabular}{lllr}
\hline \hline R-squared & 0.259916 & Mean dependent var & -1.324639 \\
Adjusted R-squared & 0.219912 & S.D. dependent var & 0.267227 \\
S.E. of regression & 0.236022 & Sum squared resid & 2.061139 \\
F-statistic & 6.497169 & Durbin-Watson stat & 1.184895 \\
Prob(F-statistic) & 0.003817 & & \\
\hline \hline
\end{tabular}

Gambar 12. Uji Signifikansi Substruktur I

Sumber: Hasil Pengelolaan data (2021)

Nilai Prob. (F-statistik) dihitung menggunakan hasil pengujian di atas, untuk substruktur persamaan I sebesar 0,003817 lebih kecil dari nilai signifikansi 0,05, maka dapat disimpulkan bahwa Non Performing Loan (NPL) dan BI Rate berpengaruh signifikan terhadap Return On Asset (ROA) variabel bila digunakan bersama-sama atau bersamaan. 


\begin{tabular}{llll}
\hline \hline & & & \\
R-squared & 0.325454 & Mean dependent var & 2.808850 \\
Adjusted R-squared & 0.269242 & S.D. dependent var & 0.236891 \\
S.E. of regression & 0.202504 & Sum squared resid & 1.476290 \\
F-statistic & 5.789746 & Durbin-Watson stat & 0.729539 \\
Prob(F-statistic) & 0.002452 & & \\
\hline
\end{tabular}

Gambar 13. Uji Signifikansi Substruktur II

Sumber: Hasil Pengelolaan data (2021)

Berdasarkan berdasarkan hasil pengujian diatas, diperoleh nilai Prob. (F-statistics) untuk persamaan substruktur II adalah 0,002457 lebih kecil dari nilai signifikansi 0,05, maka dapat disimpulkan Non Performing Loan (NPL), BI Rate dan Retrun On Assets (ROA) secara bersamasama atau simultan berpengaruh signifikan terhadap variabel harga saham sebesar 26,92 \%, sisanya sebesar $73.08 \%$ dipengaruhi oleh faktor-faktor lain yang tidak terdapat pada penelitian ini.

\section{Uji Koefisien Determinasi}

Uji koefisien determinasi digunakan untuk menilai kemampuan variabel bebas dalam menjelaskan variabel terikat. Tabel berikut menunjukkan angka statistik untuk koefisien determinasi substruktur I :

\begin{tabular}{lrlr}
\hline \hline R-squared & 0.259916 & Mean dependent var & -1.324639 \\
Adjusted R-squared & 0.219912 & S.D. dependent var & 0.267227 \\
S.E. of regression & 0.236022 & Sum squared resid & 2.061139 \\
F-statistic & 6.497169 & Durbin-Watson stat & 1.184895 \\
Prob(F-statistic) & 0.003817 & & \\
\hline \hline
\end{tabular}

Gambar 14.Uji Koefisien Determinasi substruktur I

Sumber: Hasil Pengelolaan data (2021)

Berdasarkan tabel di atas, koefisien determinasi (Adjusted Rsquared) untuk variabel Return On Assets (ROA) adalah sebesar 0,219912. Nilai tersebut dapat diartikan sebagai berikut: Non Performing Loan (NPL) dan BI Rate mempengaruhi Return On Asset (ROA) sebesar 21,99 persen, sedangkan sisanya sebesar 78,01 persen dipengaruhi oleh faktor lain yang tidak diteliti dalam penelitian ini.

\begin{tabular}{llll}
\hline \hline & & & \\
R-squared & 0.325454 & Mean dependent var & 2.808850 \\
Adjusted R-squared & 0.269242 & S.D. dependent var & 0.236891 \\
S.E. of regression & 0.202504 & Sum squared resid & 1.476290 \\
F-statistic & 5.789746 & Durbin-Wats on stat & 0.729539 \\
Prob(F-statistic) & 0.002452 & & \\
\hline \hline
\end{tabular}

Gambar 15. Uji Koefisien Determinasi substruktur II

Sumber: Hasil Pengelolaan data (2021)

Berdasarkan tabel di atas, koefisien determinasi (Adjusted Rsquared) untuk variabel harga saham adalah sebesar 0,269242 yang artinya Non Performing Loan (NPL), BI Rate, dan Return On Asset (ROA) semuanya mempengaruhi harga saham secara simultan atau bersama-sama.

Persamaan Regresi Data Panel dan Uji Signifikansi Pengaruh Parsial (Uji t)

Uji statistik $\mathrm{t}$ pada dasarnya menunjukkan seberapa jauh satu variabel independen secara individual atau parsial dapat menerangkan variasi variabel terikat. Hasil uji statistik $t$ tersaji pada tabel tabel berikut ini.

\begin{tabular}{crrrr}
\hline \hline — Variable & Coefficient & Std. Error & t-Statistic & Prob. \\
\hline \hline C & -2.626728 & 0.744364 & -3.528824 & 0.0011 \\
NPL & -0.813792 & 0.265705 & -3.062761 & 0.0041 \\
BI & 0.279801 & 0.376834 & 0.742504 & 0.4625 \\
\hline \hline
\end{tabular}

Gambar 16. Nilai statistik dari Uji t Substruktur I 
Sumber: Hasil Pengelolaan data (2021)

Berdasarkan hasil pengujian diatas, diperoleh nilai statistik dari Uji $\mathrm{t}$ dan menghasilkan persamaan substruktur I sebagai berikut.

$\mathrm{Y}=-2.626-0.813 X_{1}+0.279 X_{2}$

1. Berdasarkan hasi pengujian Regresi Data Panel dan Uji Signifikansi Pengaruh Parsial (Uji t), diperoleh nilai coefficient Non Performing Loan (NPL) sebesar (- 0.813) dan nilai signifikansi sebesar 0.0011 lebih kecil dari nilai 0.05. Sehingga dapat disimpulkan bahwa Non Performing Loan (NPL) berpengaruh negatif dan signifikan terhadap Retrun On Assets (ROA).

2. Berdasarkan hasil pengujian Regresi Data Panel dan Uji Signifikansi Pengaruh Parsial (Uji t), diperoleh nilai coefficient BI Rate sebesar 0.279 dan nilai signifikansi sebesar 0.46 lebih besar dari 0.05. Sehingga dapat disimpulkan bahwa BI Rate berpengaruh positif dan tidak signifikan terhadap Retrun On Assets (ROA).

\begin{tabular}{crrrr}
\hline \hline - Variable & Coefficient & Std. Error & t-Statistic & Prob. \\
\hline \hline C & 1.984442 & 0.507181 & 3.912693 & 0.0004 \\
NPL & -0.410814 & 0.175705 & -2.338088 & 0.0251 \\
BI & -1.167369 & 0.224936 & -5.189776 & 0.0000 \\
ROA & 0.285026 & 0.095191 & 2.994240 & 0.0050 \\
\hline \hline
\end{tabular}

Gambar 17. Nilai statistik dari Uji t Substruktur II

Sumber: Hasil Pengelolaan data (2021)

Berdasarkan hasil pengujian diatas, diperoleh nilai statistik dari Uji $\mathrm{t}$ dan menghasilkan persamaan substruktur II sebagai berikut.

$\mathrm{Y}=1.984-0.410 X_{1}-1.167 X_{2}+0.285 X_{3}$

1. Berdasarkan hasi pengujian Regresi Data Panel dan Uji Signifikansi Pengaruh Parsial (Uji t), diperoleh nilai coefficient Non Performing Loan (NPL) sebesar (- 0.410) dan nilai signifikansi sebesar 0.025 lebih kecil dari nilai 0.05 . Sehingga dapat disimpulkan bahwa Non Performing Loan (NPL) berpengaruh negatif dan signifikan terhadap Harga Saham.

2. Berdasarkan hasi pengujian Regresi Data Panel dan Uji Signifikansi Pengaruh Parsial (Uji t), diperoleh nilai coefficient BI Rate sebesar $(-1.167)$ dan nilai signifikansi sebesar 0.00 lebih kecil dari nilai 0.05 . Sehingga dapat disimpulkan bahwa BI Rate berpengaruh negatif dan signifikan terhadap Harga Saham.

3. Berdasarkan hasi pengujian Regresi Data Panel dan Uji Signifikansi Pengaruh Parsial (Uji t), diperoleh nilai coefficient Retrun On Assets (ROA) sebesar 0.286 dan nilai signifikansi sebesar 0.005 lebih kecil dari nilai 0.05. Sehingga dapat disimpulkan bahwa Retrun On Assets (ROA) berpengaruh positif dan signifikan terhadap Harga Saham.

\section{Uji Mediasi}

Uji mediasi dilakukan untuk mengetahui apakah hubungan yang melalui sebuah variabel mediasi secara signifikan mampu menjadi mediator dalam hubungan tersebut (Ghozali, 2015). Variabel mediasi atau intervening dalam penelitian ini adalah Retrun On Assets (ROA). Peneliti menggunakan Sobel Test Online dimana hasil pengujian ditambilkan pada gambar berikut :

\begin{tabular}{|c|c|c|c|c|}
\hline Input: & & Test statistic: & Std. Error: & $p$-value: \\
\hline \begin{tabular}{l|l} 
a & -0.813792
\end{tabular} & Sobel test: & -2.14106858 & 0.10833463 & 0.03226851 \\
\hline$b \quad 0.285026$ & Aroian test: & -2.08499843 & 0.11124799 & 0.03706944 \\
\hline$s_{\mathrm{a}} 0.265705$ & Goodman test: & -2.20192003 & 0.10534074 & 0.02767096 \\
\hline $\begin{array}{lll}s_{\mathrm{b}} & 0.095191\end{array}$ & Reset all & & Calculate & \\
\hline
\end{tabular}

Gambar 18. Sobel Test NPL Terhadap Harga Saham Melalui ROA Sumber: Hasil Pengelolaan data (2021) 
Berdasarkan hasil pengujian sobel test online diperoleh nilai $p$-value sebesar 0.032 , dimana nilai ini lebih kecil dari 0.05 atau 5\%. Sehingga dapat ditarik kesimpulan Retrun On Assets (ROA) secara signifikan memediasi pengaruh Non Performing Loan (NPL) terhadap harga saham.

\begin{tabular}{|c|c|c|c|c|c|}
\hline & Input: & & Test statistic: & Std. Error: & $p$-value: \\
\hline$a$ & 0.279801 & Sobel test: & 0.72067714 & 0.11066059 & 0.47110818 \\
\hline$b$ & 0.285026 & Aroian test: & 0.68555856 & 0.11632932 & 0.49299152 \\
\hline$s_{a}$ & 0.376834 & Goodman test: & 0.761812 & 0.10468536 & 0.44617222 \\
\hline$s_{\mathrm{b}}$ & 0.095191 & Reset all & \multicolumn{3}{|c|}{ Calculate } \\
\hline
\end{tabular}

Gambar 19. Sobel Test BI Rate Terhadap Harga Saham Melalui ROA

Sumber: Hasil Pengelolaan data (2021)

Berdasarkan hasil pengujian sobel test online diperoleh nilai $p$-value sebesar 0.47 , dimana nilai tersebut lebih besar dari 0.05 atau 5\%. Sehingga dapat ditarik kesimpulan Retrun On Assets (ROA) tidak memediasi pengaruh BI Rate terhadap harga saham.

\section{PEMBAHASAN}

\section{Pengaruh Non Performing Loan (NPL) Terhadap Retrun On Assets (ROA)}

Berdasarkan hasil pengujian yang telah dilakukan bahwa Non Performing Loan (NPL) memiliki pengaruh negatif dam signifikan terhadap Retrun On Assets (ROA). Hal ini karena semakin tinggi Non Performing Loan (NPL) atau rasio kredit bermasalah maka akan mengurangi pendapatan operasional bank yang berupa bunga dan berdampak pada menurunnya rasio profitabilitas yaitu Retrun On Assets (ROA). Penelitian ini mendukung studi yang dilakukan oleh (Uthami Putri Warsa \& Mustanda, 2016), (Rachmawati \& Marwansyah, 2019), (Darmawan et al., 2020) yang membuktikan bahwa Non Performing Loan (NPL) berpengaruh negatif dan signifikan terhadap Retrun On Assets (ROA) sehingga dapat disimpulkan H1 diterima. Manajemen bank perlu mengeluarkan kebijakan untuk meningkatkan system pengawasan mutu kredit dan kredibilitas debitur (Van Anh et al., 2020).

\section{Pengaruh BI Rate Terhadap Retrun On Assets (ROA)}

Berdasarkan hasil pengujian dan analisis yang telah dilakukan peneliti, dapat diketahui bahwa BI Rate memiliki pengaruh positif tetapi tidak signifikan terhadap Retrun On Assets (ROA). BI Rate adalah salah satu kebijakan moneter yang dikeluarkan oleh Bank Indonesia untuk mempengaruhi jumlah uang yang beredar. Kebijakan ini menggunakan saluran bank dalam penerapannya (Zulkhibri, 2018). Kenaikan BI Rate akan meningkatkan minat perbankan untuk menambah simpanan di bank sentral guna meraih pendapatan yang lebih besar dari sebelumnya. Untuk meningkatkan simpanan di bank sentral, masing-masing bank akan berfokus menarik masyarakat umum untuk menyimpan uang di bank, yang akan meningkatkan pendapatan bank. (Setiawan \& Hanryono, 2016). Walapun BI Rate berdampak positif terhadap Retrun On Assets (ROA) tetapi tidak signifikan terhadap naiknya pendapatan bank, hal ini disebabkan naiknya BI Rate juga menyebabkan perubahan perilaku masyarakat dalam meminjam uang di bank diakibatkan naiknya suku bunga pinjaman. Hasil ini tidak sejalan dengan kajian yang dilakukan oleh (Kurniawati et al., 2018), (Sawitri, 2018), (Purnamasari, 2015), (Bustani, 2020), (Nurhayati \& Nur Bhakti Pertiwi, 2021), (Herawati \& Putra, 2018) bahwa BI Rate berpengaruh negatif dan signifikan terhadap Retrun On Assets (ROA). Sehingga dapat disimpulkan bahwa $\mathrm{H}_{2}$ ditolak.

\section{Pengaruh Retrun On Assets (ROA) Terhadap Harga Saham}

Berdasarkan hasil pengujian dan analisis yang telah dilakukan peneliti, dapat diketahui bahwa Retrun On Assets (ROA) berpengaruh positif dan signifikan terhadap Harga Saham. Hal ini karena semakin tinggi Retrun On Assets (ROA) menunjukan bahwa manajemen bank telah menggunakan asset secara efisien dalam menghasilkan laba. menurut (Milosevic-Avdalovic \& Milenkovic, 2017) Retrun On Assets (ROA) memberikan kontribusi unik dan signifikan terhadap fluktuasi harga saham secara statistik. Sehingga apabila Retrun On Assets (ROA) tinggi investor 
akan membeli saham perusahaan bank. Penelitian ini mendukung studi yang dilakukan (Wahyuni Latif et al., 2021), (Purnamasari, 2015), (Bustani, 2020), (Nurhayati \& Nur Bhakti Pertiwi, 2021), (Herawati \& Putra, 2018), bahwa Retrun On Assets (ROA) berpengaruh positif dan signifikan terhadap harga saham. Sehingga dapat disimpulkan $\mathrm{H}_{3}$ diterima.

\section{Pengaruh Non Performing Loan (NPL) Terhadap Harga Saham}

Rasio Non Performing Loan (NPL) merupakan rasio fundamental perbankan. Rasio ini penting untuk dianalisis bagi investor, karena bisnis utama perbnakan adalah menghimpun dana dari masyarakat dan menyalurkan kembali dalam bentuk pinjaman atau kredit. Berdasarkan hasil pengujian dan analisis yang telah dilakukan peneliti, dapat diketahui bahwa Non Performing Loan (NPL) berpengaruh negatif dan signifikan terhadap Harga Saham. Hal ini menunjukan bahwa semakin tinggi rasio kredit bermasalah atau Non Performing Loan (NPL) akan berdampak pada turunya harga saham bank. Penelitian ini mendukung kajian yang dilakukan (Haq et al., 2020), (Devi, 2016), (Munawar \& Maulana, 2019), (Brastama \& Yadnya, 2020) dan (Nurhayati \& Nur Bhakti Pertiwi, 2021) Non Performing Loan (NPL) memiliki pengaruh negatif tetapi tidak signiffikan terhadap harga saham. Sehingga dapat disimpulkan $\mathrm{H}_{4}$ diterima.

\section{Pengaruh BI Rate Terhadap Harga Saham}

Berdasarkan hasil pengujian dan analisis yang telah dilakukan peneliti, dapat diketahui bahwa BI Rate berpengaruh negatif dan signifikan terhadap Harga Saham. Hal ini menunjukan bahwa kenikan BI Rate akan berpengaruh terhadap turunnya harga saham bank. Kenaikan BI Rate secara langsung akan berdampak pada rasio keuangan bank, hal ini karena kebijakan BI Rate menggunakan saluran bank dalam penerapannya (Zulkhibri, 2018). Hasil ini mendukung kajian yang dilakukan oleh (Türsoy, 2017), (Arhenful et al., 2021) dan (Narayan et al., 2014) bahwa suku bunga memiliki pengaruh negatif dan signifikan terhadap harga saham. Sehingga dapat disimpulkan $\mathrm{H}_{5}$ diterima.

\section{Peran Retrun On Assets (ROA) Sebagai Variabel Mediasi Pada Pengaruh Non Performing Loan (NPL) Terhadap Harga Saham.}

Berdasarkan hasil pengujian dan analisis yang telah dilakukan peneliti, dapat diketahui bahwa Retrun On Assets (ROA) secara signifikan memediasi pengaruh Non Performing Loan (NPL) terhadap harga saham. Hal ini menunjukan bahwa apabila rasio kredit bermasalah atau Non Performing Loan (NPL) tinggi akan berpengaruh pada menurunnya pendapatan oprasional bank sehingga akan mempengaruhi kinerja bank dan secara tidak langsung Non Performing Loan (NPL) mempengaruhi harga saham melalui Retrun On Assets (ROA). Hal ini akan mempengaruhi keputusan investor untuk berinvestasi dan dapat mempengaruhi harga saham. Hasil ini didukung oleh kajian yang dilakukan (Kusumaningrum \& Iramani, 2020), (Brastama \& Yadnya, 2020) bahwa Non Performing Leon (NPL) memiliki pengaruh negatif dan signifikan terhadap harga saham melalui Retrun On Assets (ROA) sebagai variabel mediasi. Sehingga dapat disimpulkan $\mathrm{H}_{6}$ diterima.

\section{Peran Retrun On Assets (ROA) Sebagai Variabel Mediasi Pada Pengaruh BI Rate Terhadap Harga Saham}

Berdasarkan hasil pengujian dan analisis yang telah dilakukan peneliti, dapat diketahui bahwa Retrun On Assets (ROA) tidak memediasi pengaruh BI Rate terhadap harga saham. Hal ini menunjukan tinggi dan rendahnya BI Rate tidak mempengaruhi harga saham melalui Retrun On Assets (ROA). Hasil ini memberikan gambaran bahwa keputusan investor dalam berinvestasi pada saham bank uuum BUMN tidak dipengaruhi oleh BI Rate melalui Retrun On Assets (ROA), atau dengan kata lain bank BUMN mampu mempertahankan kinerjanya terhadap perubahan kebijakan suku bunga (BI Rate) sehingga tidak berpengaruh terhadap harga saham. Hasil ini tidak sejalan dengan penelitian yang dilakukan oleh (Kusumaningrum \& Iramani, 2020), (Wiratno et al., 2018) bahwa Retrun On Assets (ROA) tidak mampu memediasi pengaruh antara suku bunga terhadap harga saham. Sehingga dapat disimpulkan $\mathrm{H}_{7}$ ditolak. 


\section{KESIMPULAN}

Berdasarkan hasil dan pembahasan yang telah dilakukan, diperoleh kesimpulan secara simultan Non Performing Loan (NPL), BI Rate dan Retrun On Assets (ROA) berpengaruh signifikan terhadap harga saham. Secara parsial 1). Kredit bermasalah (NPL) memiliki dampak negatif dan signifikan terhadap Return On Assets (ROA). 2) BI Rate berdampak positif namun tidak signifikan terhadap Return On Asset (ROA). 3). NPL (Non Performing Loan) memiliki dampak negatif dan signifikan terhadap harga saham. 4). BI Rate memiliki dampak negatif dan signifikan terhadap harga saham. 5) Return On Assets (ROA) memiliki dampak positif dan signifikan terhadap harga saham. Retrun On Assets (ROA) sebagai variabel mediasi mampu memdiasi pengaruh kredit bermasalah (NPL) terhadap harga saham namun, Retrun On Assets (ROA) tidak memediasi pengaruh BI Rate terhadap harga saham.

\section{UCAPAN TERIMA KASIH}

Puji syukur kami panjatkan kepada Allah SWT, karena berkat ridho dan karunia-Nya kami dapat menyelesaikan tulisan ini. Selanjutnya, ucapan terima kasih kami sampaikan kepada pihak pihak yang telah mendukung dan berkontribusi terhadap penelitian ini antara lain kepada orang tua kami, Bpk. Sunarno dan Ibu Sutiamah, kepada saudara dan keluarga, kepada para dosen yang telah membimbing kami serta kepada seluruh teman teman seperjuangan Mahasiswa Pascasarjana Ekonomi Syariah UIN Maulana Malik Ibrahim Malang.

\section{REFERENSI}

Alaagam, A. (2019). The Relationship Between Profitability and Stock Prices: Evidence from the Saudi Banking Sector. July. https://doi.org/10.7176/RJFA

Amos John, T. (2018). Effect of Non-Performing Loans on Bank Performance of Some Selected Commercial Bank in the Nigerian Banking Sector. International Journal of New Technology and Research, 4(4), 263089.

Arhenful, P., Kwadwo Yeboah, A., \& Sarfo Adjei, K. (2021). Effect of Interest Rate on Stock Prices in Ghana Peter. 12(1), 1-7. https://emea.mitsubishielectric.com/ar/productssolutions/factory-automation/index.html

Bank Indonesia. (2020). Operasi Moneter. Bank Indonesia. https://www.bi.go.id/id/fungsiutama/moneter/operasi-moneter/Default.aspx\#floating-2

Brastama, R. F., \& Yadnya, I. P. (2020). The Effect of Capital Adequacy Ratio and Non Performing Loan on Banking Stock Prices with Profitability as Intervening Variable. American Journal of Humanities and Social Sciences Research (AJHSSR), 4(12), 43-49.

Bustani. (2020). The Effect Of Return On Assets (ROA), Net Profit Margin (NPM), Dividend Payout Ratio (DPR) And Dividend Yield (DY) On Stock Prices In The Subsectors Insurance Company Listed In Indonesia Stock Exchange Period 2015-2018. Ilomata International Journal of Tax and Accounting, 1(3), 170-178. https:/doi.org/10.52728/ijtc.v1i3.113

Darmawan, J., Laksana, B., \& Danisworo, D. S. (2020). Pengaruh Non Performing Loan dan BI Rate terhadap Return on Asset Pada Bank Umum. Indonesian Journal of Economics and Management, Vol 1(1), 174-183.

Dayu, Q. P. (2015). Pengaruh Tingkat Kecukupan Modal, Likuiditas, Risiko Pasar, Dan Risiko Kredit Terhadap Kinerja Keuangan Pada Bank Konvensional (Studi Empiris Pada Bank Konvensional Terdaftar Di BEI). Jurnal Akuntansi, 3(1).

Devi, W. N. (2016). Analisis Pengaruh Kinerja Keuangan Terhadap Harga Saham Bank BUMN Di BEI Periode 2006-2015). Jurnal Perbanas, 2(1).

El - Heze. (2021). Cara Menghitung Non Performing Loan (NPL) pada Laporan Keuangan Bank. Saham Gain. sahamgain.com/2018/04/cara-menghitung-non-performing-loan-npl.html

Ghozali, I. (2015). Aplikasi Analisis Multivariate Dengan Program SPSS. Gramedia.

Gujarati, D. . (2015). Ekonometrika Dasar. Erlangga.

Haq, M. F. A., Zulkhairahmi, Febriananda, A., Muhammad Nuur Ihsan Rabbani Tarmaja, \& Christine, D. (2020). The Influence Of Non-Performing Loans And Capital Adequacy Ratio On Share Prices ( Empirical Study Of Banking Registered On The Ise For The 2016-2018 
Period ). Palarch's Journal Of Archaeology Of Egypt/Egyptology, 17(4), 2887-2896.

Herawati, A., \& Putra, A. S. (2018). The influence of fundamental analysis on stock prices: The case of food and beverage industries. European Research Studies Journal, 21(3), 316-326. https $/ /$ doi.org/10.35808/ersj/1063

Indriani, N., \& Dewi, S. (2016). Pengaruh Variabel Tingkat Kesehatan Bank Terhadap Harga Saham Perbankan Di Bursa Efek Indonesia. E-Jurnal Manajemen Universitas Udayana, 5(5), 255183.

Kurniawati, S., Hamzah, Z., \& Kunawangsih, T. (2018). Analisis Pengaruh CAR, LDR, DER, BI Rate dan Inflasi Terhadap ROA pada 10 Bank Besar yang Ada di Bursa Efek Indonesia. Hukum, Politik, Manajemen, Ekonomi, Akuntansi, Konseling, Desain Dan Seni Rupa", 1999 , $1183-1190$. http://www.trijurnal.lemlit.trisakti.ac.id/index.php/semnas/article/download/3497/2963

Kusumaningrum, D. R., \& Iramani. (2020). Effect of Financiap Performance on Stock Price With Return On Asset as an Intervening Variable in State Owned Banks Indonesia. International Journal of Multicultural and Multireligious Understanding, 7(2), 321-336.

Martiningtiyas, C. R., \& Nitinegeri, D. T. (2020). The Effect of Non-Performing Loans on Profitability in Banking Sector in Indonesia. 151(Icmae), 64-67. https $/ /$ doi.org/10.2991/aebmr.k.200915.016

Milosevic-Avdalovic, S., \& Milenkovic, I. (2017). Impact of company performances on the stock price: An empirical analysis on select companies in Serbia. Ekonomika Poljoprivrede, 64(2), 561-570. https://doi.org/10.5937/ekopolj1702561m

Munawar, A. H., \& Maulana, Y. S. (2019). Stock Performance Analysis As the Impact of Non Performing Loan Determination On Profitability. 4(2), 145-156.

Narayan, P. K., Narayan, S., \& Singh, H. (2014). The determinants of stock prices: New evidence from the Indian Banking Sector. Emerging Markets Finance and Trade, 50(2), 5-15. https:/doi.org/10.2753/REE1540-496X500201

Nurhayati, E., \& Nur Bhakti Pertiwi, W. (2021). Analisis Pengukuran Faktor Paling Dominan yang Mempengaruhi Harga Saham Perbankan BUMN Indonesia Periode 2009 - 2018. $\operatorname{XIII}(2), 230-256$.

OCBC NISP. (2021). Pengertian BI Rate, Fungsi, dan Bedanya dengan BI Repo Rate.

Osuagwu, E. S. (2014). Determinants of Bank Profitability in Nigeria. International Journal of Economics and Finance, 6(12), 46-63. https://doi.org/10.5539/ijef.v6n12p46

Processing Data Penelitian Kuantitatif Menggunakan Eviews. (2013). Journal of Chemical Information and Modeling, 53(9), 1689-1699.

Purnamasari, D. (2015). The Effect of Changes in Return on Assets , Return on Equity , and Economic Value Added to the Stock Price Changes and Its Impact on Earnings Per Share. Journal of Accounting (ISSN 2222-2847), 6(6), 80-90.

Rachmawati, S., \& Marwansyah, S. (2019). Pengaruh Inflasi, BI Rate, CAR, NPL, BOPO Terhadap Profitabilitas Pada Bank BUMN. Jurnal Mantik, 3, 117-122.

Rohimah, E. (2021). Analisis Pengaruh BOPO, CAR, Dan NPL Terhadap ROA Pada Bank BUMN Tahun 2012-2019 (Studi pada Bank BUMN yang Go Public di Bursa Efek Indonesia). JIMA Jurnal Ilmiah Mahasiswa Akuntansi, 1(2), 133-145.

Rumah.com. (2021). Memahami Non Performing Loan (NPL) di Indonesia. https $/ /$ www.rumah.com/panduan-properti/npl-non-performing-loan-53934\#: :text=Non Performing Loan (NPL) adalah,dijadwalkan untuk jangka waktu tertentu.

Sawitri, N. N. (2018). The Prediction of Third Party Funds, Interest Rates, and Non-Performing Loans toward Loan To Deposit Ratios and Its Impact on Return on Assets on Commercial Banks in Indonesia. Jurnal Manajemen, 22(3), 409. https://doi.org/10.24912/jm.v22i3.430

Setiawan, D. I., \& Hanryono. (2016). Analisis Pengaruh Kinerja Keuangan Bank, Tingkat Inflasi dan BI Rate terhadap Pertumbuhan Laba. Journal of Accounting and Business Studies, 1(September), 98-110. ISSN \# 2540-8275

Sugiyono. (2017). Metode Penelitian Kuantitatif dan Kualitatif. Alfabeta.

Türsoy, T. (2017). Causality between stock prices and exchange rates in Turkey: Empirical evidence from the ARDL bounds test and a combined cointegration approach. International 
Journal of Financial Studies, 5(1). https://doi.org/10.3390/ijfs5010008

Undang-Undang No. 8 Tahun 1995 Tentang Pasar Modal. https://www.ojk.go.id/id/kanal/pasarmodal/regulasi/undang-undang/Documents/Pages/undang-undang-nomor-8-tahun-1995tentang-pasar-moda//UU Nomor 8 Tahun 1995 (official).pdf

Uthami Putri Warsa, N. M. I., \& Mustanda, I. K. (2016). Pengaruh CAR, LDR Dan NPLTerhadap ROA Pada Sektor Perbankan Di Bursa Efek Indonesia. E-Jurnal Manajemen Universitas Udayana, 5(5), 253810.

Van Anh, T. T., Nhung, N. T., \& Tu, T. T. T. (2020). Dealing with non-performing loans during the bank restructuring process in Vietnam: Assessment using the AHP and topsis methods. Gadjah Mada International Journal of Business, 22(3), 323-347. https $/ /$ doi.org/10.22146/GAMAIJB.44453

Wahyuni Latif, I., Murni, S., \& N. Tawas, H. (2021). Analisis Capital Adequacy Ratio (CAR), Non Performing Loan (NPL), Loan To Deposit Ratio (LDR), Debt To Equity Ratio (DER), Dan Return On Asset (ROA) Terhadap Harga Saham Pada Perusahaan Sektor Perbankan Yang Terdaftar Di Bursa Efek Indonesia (Periode 2015. Jurnal EMBA: Jurnal Riset Ekonomi, Manajemen, Bisnis Dan Akuntansi, 9(4), 203-215.

Wiratno, A., Kurniasari, W., \& Yusuf, M. (2018). Pengaruh Inflasi Dan Suku Bunga Terhadap Return Saham Dengan Profitabilitas Sebagai Variabel Intervening Di Perbankan Yang Terdaftar Di Bursa Efek Indonesia Tahun 2013-2015. Journal of Accounting Science, 2(1), 67-90. https://doi.org/10.21070/jas.v2i1.1216

Zulkhibri, M. (2018). The impact of monetary policy on Islamic bank fi nancing : bank-level evidence from Malaysia. 23(46), 306-322. https://doi.org/10.1108/JEFAS-01-2018-0011 